\title{
ФОРМУВАННЯ ДІАГНОСТИЧНИХ КОМПЕТЕНЦІЙ У МАЙБУТНІХ УЧИТЕЛІВ ПОЧАТКОВОЇ ШКОЛИ
}

\begin{abstract}
Мартиненко С. М. Формування діагностичних компетенцій у майбутніх учителів початкової школи.

У статті обтрунтовано систему діагностичних компетенцій, якими мають володіти майбутні вчителі початкової школи; визначено поетапність їх формування; охарактеризовано основні компоненти формування діагностичних компетенцій у майбутніх учителів початкової школи під час професійної підготовки.
\end{abstract}

Ключові слова: діагностичні компетениії, діагностична компетентність, основні етапи та компоненти формування діагностичних компетенцій майбутніх учителів початкової школи.

Мартыненко С. Н. Формирование диагностический компетенций у будущих учителей начальной школь.

В статье обоснована система диагностических компетенций, которыми должны владеть будущие учителя начальной школь, определена этапность их формирования; охарактеризованы основные компоненты формирования диагностических компетенций у будущих учителей начальной школь во время профессиональной подготовки.

Ключевые слова: диагностические компетенщии, диагностическая компетентность, основные этапы и компоненты формирования диагностических компетенций будущего учителя начальной школьл.

Martynenko S. Formation of the diagnostic competences of future teachers of elementary school.

In the article the system of diagnostic skills, which should have future teachers of primary school identified a staged their formation, described the main components forming the diagnostic skills of primary school teachers during their training.

Key words: diagnostic competence, diagnostic competence, milestones and components forming the diagnostic competence of future teacher of primary school.

Постановка проблеми. В умовах оновлення й реформування навчально-виховного процесу сучасної школи, здійснення особистісно зорієнтованого підходу до особистості молодшого школяра вагомого значення набуває проблема формування діагностичних компетенцій у майбутніх учителів початкової школи, які є складовими діагностичної компетентності, необхідною для якісної та продуктивної педагогічної діяльності.

Актуальність порушеної проблеми $\epsilon$ очевидною, тому що для створення життєтворчого навчального середовища сучасному вчителю необхідно не лише досконало володіти знаннями з навчального предмета, прийомами педагогічної майстерності, а й бути інженером дитячих душ, знати індивідуальні особливості та характеристики кожної дитини, володіти методами її вивчення.

Сучасний педагог має бути дослідником, уміти здійснювати моніторинг, діагностування навчально-виховного процесу й учня зокрема, тобто мати сформовану систему діагностичних знань і вмінь, що складає діагностичну компетентність, яка $\epsilon$ результатом набуття діагностичних компетенцій, тобто іï складових, вимог до діагностичної підготовки вчителя 
початкової школи, необхідних для якісної та продуктивної педагогічної діяльності.

Діагностична компетентність, на нашу думку, $\epsilon$ інтегрованою здатністю особистості (вчителя) на основі знань педагогічної діагностики, сформованих діагностичних умінь, навичок, досвіду вивчати, досліджувати та прогнозувати розвиток навчально-виховного процесу загалом i конкретного учня зокрема.

Аналіз останніх досліджень і публікацій 3 окресленої проблеми. Проаналізувавши праці сучасних науковців (Н. Бібік, Л. Ващенко, Л. Карпова, I. Зимня, О. Овчарук, О. Пометун, О. Савченко, Л. Хоружа), пов’язаних із дослідженням проблеми формування професійної компетентності майбутніх педагогів, ми встановили, що проблема формування діагностичних компетенцій у майбутніх учителів початкової школи є вивченою недостатньо. 3 урахуванням зазначеного наші зусилля будуть спрямовані на розкриття досліджуваного питання.

У запропонованій статті, беручи до уваги актуальність окресленої проблеми та зважаючи на ступінь iï теоретичної та практичної розробленості, ставимо за мету визначити та охарактеризувати основні компоненти i поетапність формування діагностичних компетенцій у майбутніх учителів початкової школи у процесі їх професійної підготовки.

Виклад основного матеріалу дослідження. У процесі теоретикоекспериментального дослідження встановлено, що формування діагностичних компетенцій у майбутніх учителів початкової школи відбувається у процесі вивчення психолого-педагогічних дисциплін, фахових методик, науководослідної діяльності, педагогічної практики та розробленого спецкурсу «Основи діагностичної діяльності вчителя початкової школи».

Зупинимось детальніше на розкритті сутності компонентів формування діагностичних компетенцій у майбутніх учителів початкової школи.

В основу організації навчального процесу було покладено принцип додатковості у його спрощеній інтерпретації, за умов якого зберігаються традиційні підходи до професійної підготовки студентів, а підготовка до діагностичної діяльності органічно входить до загального контексту, доповнюючи та збагачуючи його.

На нашу думку, для того, щоб сформувати діагностичні компетенції, необхідно чітко визначити коло діагностичних знань i вмінь та поелементарно структурувати їх, виокремивши основні інформаційні компетенції, що підлягають засвоєнню. Варто встановити також порядок їх введення, час, дисципліни і теми занять, у процесі вивчення яких ці компетенції будуть формуватися.

Розроблену нами систему діагностичних компетенцій подано трьома групами:

I група - знання про сутність і зміст діагностичної діяльності (роль діагностичної діяльності в професійній діяльності вчителя початкової 
школи; знання про мету, завдання, засоби, функції діагностичної діяльності, склад іï дій та специфіку);

II група - знання теорії педагогічної діагностики (об’єкт, предмет, спрямованість педагогічної діагностики, методи, прийоми i засоби педагогічної діагностики, які охоплюють вимоги до проведення педагогічного спостереження, анкетування, тестування, вивчення «продукції» учнів, оцінювання, моніторингу, прогнозування тощо);

III група - знання технології діагностичної діяльності, тобто діагностичні методики та технології, діагностичний супровід професійної діяльності вчителя початкової школи, що охоплює п’ять основних етапів педагогічної діагностики, починаючи 3 тестування шестилітньої дитини щодо іiі готовності до навчання в школі та закінчуючи четвертим класом (закінчення початкової школи) і перехід до основної школи.

Для ефективності процесу формування діагностичних компетенцій майбутніх учителів початкової школи було застосовано відомий у науці метод вивчення структури діяльності, сутність якого полягала в тому, що подібні порівняння дозволяють виокремлювати ті дії, які забезпечували б успіх, і відсутність яких робить діяльність малоефективною. Виокремлено основні етапи формування діагностичних компетенцій майбутніх учителів початкової иколи:

I етап (підготовчий) - прийняття професії як особистісно значущої («Вступ до спеціальності», «Загальна психологія», «Історія педагогіки», «Педагогіка»);

II етап (основний) - когнітивне засвоєння діяльності («Вікова психологія», «Педагогічна психологія», «Дидактика початкової школи», «Теорія і методика виховання»);

III етап (підсумковий) - перехід до практичних дій (вивчення фахових методик, «Основ педагогічної майстерності», «Сучасних освітніх технологій», спецкурсу «Основи діагностичної діяльності вчителя початкової школи», педагогічна практика, науково-дослідна діяльність);

IV етап (рефлексивно-корекційний) - безпосередня професійна діяльність у початковій школі вчителем-класоводом, самоаналіз та саморефлексія.

Поняття, які формуються у процесі вивчення навчальних предметів:

1. Діагностична діяльність учителя, їі мета, завдання.

2. Зміст і функції діагностичної діяльності.

3. Орієнтація та індивідуальні особливості учнів.

4. Аналітичні та рефлексивні процеси в діяльності вчителя.

5. Діагностичні вміння і навички; діагностичні компетенції.

6. Педагогічна діагностика як основа організації початкової освіти.

7. Діагностичні методики та технології вивчення індивідуальних особливостей дитини.

8. Самодіагностика й самоаналіз. 
9. Педагогічна діагностика як основа створення сприятливого навчально-виховного розвивального середовища.

10. Герменевтична сутність діагностичної діяльності вчителя.

На першому курсі у процесі вивчення навчальних предметів «Bcmyn до спеціальності», »Загальна психологія», «Історія педагогіки», "Педагогіка»на лекційних і семінарсько-практичних заняттях удосконалюються знання про місце діагностичного компонента в системі педагогічної діяльності, про мету і засоби, функції, специфіку та складові діагностичних умінь і навичок.

На другому курсі на аудиторних заняттях із навчальних дисциплін «Вікова психологія», «Педагогічна психологія», "Дидактика початкової школи» формуються поняття «діагностично визначена мета навчання», «діагностика результатів навчання», «діагностичне вивчення індивідуальних особистісних відмінностей», «індивідуальні стилі навчання» тощо.

На третьому курсі у процесі вивчення фахових методик, навчальної дисципліни «Теорія $i$ методика виховання», спецкурсу «Педагогічна деонтологія» до змістом занять охоплено поняття «діагностика вихованості школярів», «діагностичні методи виховного процесу», «моделювання та прогнозування виховання в діагностичній діяльності», «моніторинг вихованості», «етичний аспект діагностичної діяльності вчителя».

Ha IV курсі під час вивчення спецкурсу «Основи педагогічного спостереження» відбувається ознайомлення й вироблення вмінь проведення педагогічного спостереження як одного з методів діагностичної діяльності, формування діагностичного (педагогічного) мислення. Дисципліна «Основи педагогічної майстерності» дозволила сформувати такі поняття, як: «формування діагностичної компетентності», «діагностична майстерність», «діагностична функція в педагогічній майстерності», «діагностичні методи педагогічної взаємодії» тощо. У межах навчальної дисципліни «Сучасні освітні технологї» надавалась змога опрацювати поняття «технологія діагностичної діяльності», «алгоритм установлення педагогічного діагнозу», «оцінювання навчальних досягнень» тощо.

Навчальна дисципліна «Педагогічний менеджмент» уможливила введення поняття «діагностування об’єкта управління», «діагностичні методи в управлінні», «оперативна, компонентна і системна діагностика», «діагностика і моніторинг освітніх систем», «моніторинг якості освіти» тощо.

Наступний компонент - науково-дослідна робота студентів за проблемами педагогічної діагностики, створює умови для удосконалення дослідницько-пошукових навичок 3 педагогічної діагностики, розширення наукового світогляду.

Теми з педагогічної діагностики було запропоновано студентам після вивчення циклу психолого-педагогічних дисциплін, фахових методик i спецкурсу «Основи педагогічного спостереження». Вони містять актуальні проблеми розвитку педагогічної діагностики (наприклад, педагогічна діагностика - історичний аспект розвитку і сутність; методичні основи педагогічної діагностики; діагностування і прогнозування в педагогічному 
процесі; особливості діагностування психолого-педагогічної готовності шестирічної дитини до навчання в школі; діагностувальні методики вивчення навчально-пізнавальної діяльності учнів першого (другого, третього, четвертого) класу; діагностування загального фізичного розвитку дитини; діагностування динаміки розвитку мовлення; діагностика динаміки розвитку мислення тощо).

Важливим етапом $є$ також захист бакалаврських і магістерських робіт, тому що студенти мають виявити вміння презентувати результати проведеного дослідження, зробити відеопрезентацію, виявити рівень володіння діагностичним інструментарієм, методами i прийомами діагностування, робити висновки й узагальнення, працювати з науковими джерелами, довідковою літературою тощо.

Отже, науково-дослідна робота, участь у студентському науковому товаристві дають змогу майбутнім учителям початкової школи розширити діапазон їхньої компетентності з педагогічної діагностики, відпрацювати систему діагностичних технологій та методик.

Наступним, досить важливим компонентом, формування діагностичної компетентності, $є$ педагогічна практика. Відповідно до мети, завдань i основних етапів фахової підготовки вчителя початкової школи встановлено таку поетапність:

I вступний етап - педагогічна практика: «Спостереження за навчальновиховною роботою вчителя-класовода» (V семестр, III курс);

II основний етап - педагогічна практика: «Навчально-виховна» (VI семестр, III курс); «Літня практика в оздоровчих таборах» (VI семестр, III курс);

III підсумковий етап - педагогічна практика: «Виробнича» (VII семестр, IV курс), «Педагогічна практика» (IX семестр, V курс).

Наприклад, безумовно лише фрагментарно, педагогічна практика (IV семестр, III курс) дає змогу майбутнім учителям використовувати у практичній діяльності діагностичні методи (педагогічне спостереження, анкетування, тестування, прогнозування, складання характеристики на учня молодшого шкільного віку та клас), визначати у професійній діяльності вчителя початкової школи діагностичні функції; удосконалювати вміння працювати з учнями, що мають різні навчальні можливості, поведінку; здійснювати диференційований та особистісно орієнтований підхід.

До кожного виду практики складено програму, визначено педагогічні завдання як дослідницькі, так і творчі.

Відтак педагогічна практика дає змогу моделювати і відтворювати цілі фрагменти діагностичної діяльності, закріплювати теоретичні знання, здійснювати рефлексивну оцінку професійних дій, поетапно оволодівати системою професійно-педагогічних установок, мотивів, ставлень і досвіду діагностичної діяльності.

На нашу думку, важливим засобом формування діагностичної компетентності майбутніх учителів початкової школи $\epsilon$ введення до навчальних планів підготовки фахівців спеціальності «Початкова освіта» 
освітньо-кваліфікаційних рівнів «спеціаліст», «магістр» спецкурсу «Основи діагностичної діяльності вчителя початкової школи», який має професійноорієнтоване спрямування, формує ключові компетенції.

Метою викладання спецкурсу є ознайомлення студентів зі змістом, завданнями і функціями діагностичної діяльності вчителя початкової школи, діагностичними технологіями $\mathrm{i}$ методиками вивчення особливостей навчально-пізнавальної діяльності учнів молодшого шкільного віку. Кількість годин, відведених навчальним планом на вивчення дисципліни, становить 90 год., із них: 8 год. - лекції; 8 год. - семінарські заняття; 8 год - індивідуальна робота, 62 год. - самостійна робота, 4 год. - модульний контроль.

Спецкурс складається 3 двох модулів:

I модуль - теоретичного спрямування - теоретичні основи педагогічної діагностики;

II модуль - практичного спрямування - розроблення та апробація діагностичних методик і діагностичного інструментарію.

Форма контролю - залік, на який студенти готують методичне портфоліо професійної діяльності вчителя початкової школи, в якому вміщують зібрані, відповідно до етапів діагностичної діяльності, діагностичні методики, визначають методи, форми, результат і термін проведення діагностичних процедур.

Спецкурс «Основи діагностичної діяльності вчителя початкової школи» інтегрував у своєму змісті знання і вміння з навчальних дисциплін, передбачених навчальним планом підготовки майбутніх учителів початкової школи, дав змогу студентам розширити коло діагностичних компетенцій, відпрацювати діагностичні технології та методики.

Отже, основні етапи та компоненти формування діагностичних компетенцій у майбутніх учителів початкової школи підтвердили свою дієвість упродовж усього періоду навчання у вищому навчальному закладі. Запропонована поетапність ураховувала логіку вивчення психологопедагогічних, фахових дисциплін, проходження педагогічної практики, науково-дослідної роботи, уможливила передбачення взаємозв'язку i взаємозумовленості не лише самих етапів, а й основних функціональних завдань професійної підготовки в умовах багатопрофільного університету.

\section{Література}

1. Бондар В. І. Дидактика: ефективні технології навчання студентів: [навч. посіб.] / В. І. Бондар. - К. : Вересень, 1996. - 122 с.

2. Мартиненко С. М. Основи діагностичної діяльності вчителя початкової школи: [навч.-метод. посіб.] / С. М. Мартиненко. - К. : КУ імені Бориса Грінченка, 2010. - 264 с.

3. Мороз О. Г. Педагогічна практика студентів у загальноосвітніх навчальних закладах: [навч. посіб.] / О. Г. Мороз. - К., 2003. - 90 с.

4. Пехота О. М. Психолого-педагогічні основи індивідуально-орієнтованої підготовки майбутнього вчителя // Сучасна вища школа: психолого-педагогічних аспект : [монографія] / за ред. Н. Г. Ничкало. - К. : ВІПОЛ, 1999. - С. 213-235.

5. Савченко О. Я. Виховний потенціал початкової освіти / О. Я. Савченко. - К. : СПД «Цудзинович Т. І.», 2007. - 204 с.

Стаття надійшла до редакції 20.05.2012 p. 